\title{
Pattern of Character Building for Students in Middle School and Islamic Boarding Schools
}

\author{
A. Aco Agus 1 , Sukri Badaruddin ${ }^{2}$, Musria Muh. Nur ${ }^{3}$ \\ ${ }^{1,3}$ Universitas Negeri Makassar \\ ${ }^{2}$ STAIN Majene \\ E-mail: andi.aco.agus@unm.ac.id ${ }^{1}$, sukribadaruddin@stainmajene.ac.id², \\ musriamuhnur@gmail.com ${ }^{3}$
}

\begin{abstract}
This study aims to describe the pattern of character formation of students in Schools and Islamic Boarding Schools (studies on MTs Ma'Had Hadith Al-Junadiyah Biru with Watampone 3 Middle School. The subjects in this study are the Principal of Watampone 3 Middle School, Principal of Madrasah Tsanawiah Ma'Had Al-Junadiyah Blue Hadith, Religious Teachers, PPKn Teachers, Social Studies Teachers from Both Educational Institutions studied and students and students. The data collection was used by means of observation, interviews, documentation. The research instruments were supported through interview guidelines, observation guidelines and documentation documentation. The research shows that the two educational units, among others, namely SMP Negeri 3 Watampone and Madrasah Tsanawiah Ma'Had Al-Junadiyah Blue have similar character formation patterns in terms of methods while in terms of strategy formation patterns are carried out with different approaches. Watampone in terms of the method emphasizes more on the teacher's approach to the students in shaping the character of students, besides the emphasis on the integration of character education in certain subjects. In terms of strategy, SMP Negeri 3 Watampone emphasizes more on the pattern of character formation through extracurricular activities where through extracurricular activities there are 3 expected patterns of character formation, they are habituation, exemplary, and culture. while the Madrasah Tsanawiah Ma'Had Hadith Al-Junadiyah Biru strategy applied in the pattern of character education through the activity of apples every morning before entering the class to practice the discipline of students.
\end{abstract}

Keywords: Character Building; Learners; Educator; Method and Strategy

\section{INTRODUCTION}

In this current era to build and form characters that are somewhat faded and degenerate due to the negative influence of globalization, especially the value of courtesy, certainly a challenge for a teacher in forming character (Awaru, 2017; Kardilla \& Awaru, 2018; Nurlailah \& Awaru, 2018). Character education can be a hope to improve the character of the nation, especially for students, students and society in general. In this case education at the secondary school level is needed to shape the character of students in an effort to maintain the integrity of the nation's buried values (Awaru, 2017; Hamzah, 2019).

The phenomenon of waning and declining character, especially manners at the age of children, especially students is not a phenomenon that is not uncommon we see, this is a lot and we can meet around us and we can see social media and electronic media for example in school students no longer respect their teachers, courtesy and courtesy to teachers are decreasing 


\section{Jurnal Administrare: Jurnal Pemikiran Ilmiah dan Pendidikan Administrasi Perkantoran Vol. 7, No. 1, January - June 2020, Pages 83-92}

(Kahar et al., 2019; Niswaty et al., 2016; Saggaf et al., 2014; Salam \& Rosdiana, 2015). Other cases highlighted by the media related to this matter, one of which happened on Jalan Captain Panjaitan, Watampone village, Bone. Where there was a brawl between students from SMP 4 and SMP 2 who were throwing stones at each other. Amrullah, a local resident who was hit by a rock, said the stone throwing started when students from both schools taunted one another. And of course many more events that certainly show the deterioration of the character of the students.

Character is a basic trait that comes from a person's innate nature when he was born in the world, good and bad characters are formed based on the environment where a person lives, for example the family as the first environment for character formation, it's good the family is very influential for a child later (Andreadou et al., 2002; Castro et al., 2016; Procter \& Wilson, 1995). vice versa if the environment is bad, of course it will also affect the moral development of the child's character in question. According to Lickona (1999) the character definition is: "Character as" knoeing the good, desiring the good, and doing the good (Knowing good, wanting good, and doing everything good).

Forming one's character should begin early, the family as the first environment of a child is expected to provide character education which is a value education as a form of handling the problem of moral degradation. The value of character that can be given in the family environment includes the value of harmony, piety, faith, and tolerance.

Through a democratic national education system, education has the function to strengthen noble, creative, innovative, nationally, intelligent, healthy, disciplined and responsible, skilled and knowledgeable skills and mastering science and technology to develop the quality of Indonesian citizens. Character is the process of forming students' character / personality or giving guidance to students to become better and become human beings with noble character. Therefore, character education in Indonesia has the essence of education that instills noble values. Character is morality and goodness found in a person, immorality is also a character. Being moral or not is in accordance with the attitude that will be shown to others.

Character education in schools is closely related to school management or management. The intended management is how character education is planned, carried out and controlled in adequate education activities in school. The management includes, among others, the values that need to be embedded, curriculum content, learning, assessment, education and education personnel, and other related components. Thus, school management is one of the effective media in character education in schools.

Public schools are formal education systems that are managed by the government. education levels are elementary, junior high, high school. There are more general subjects than religious subjects. Public schools are more in demand among the community than free of charge Nine years of schooling, also provided with many scholarships. Besides the school family is the second educational institution that is formal and not natural. At school children are taught the skills to write, read, count and socialize. Public schools have clear, planned and organized programs that are officially established by the government such as curriculum, study hours, lesson plans and other regulations.

Based on preliminary observations at MTs Ma'Had Hadith Al-Junaidiyah Biru Bone, the existing Santri in boarding schools highlight the aspects of their spiritual intelligence, this can be seen at a glance from each activity and actions of the students who fill their rest time by memorizing and studying Al- Qur'an and Hadith, Santri shake hands when meeting each other, 
no Santri who roam outside the school. whereas in Watampone Middle School 3 you can see the difference where students prefer to spend their free time with extracurricular activities such as sports, art activities, etc. Students greet each other with known friends, and there are still many students who roam outside the school environment.

Based on these observations, the researcher concluded that there were very striking differences in terms of the character of students in the two educational institutions if the students' behavior was observed. then what is the role and way of a teacher educating, teaching, guiding, directing, assessing, and evaluating students? Therefore, researchers sought to conduct research to find out how the pattern of character formation of students in junior high schools and Islamic boarding schools.

\section{METHOD}

Research on the pattern of character formation of students in junior high schools and Islamic boarding schools uses a qualitative approach. This research was conducted at MTs Ma'Had Hadith Al-Junaidiyah Biru Bone and SMPN 3 Watampone. The subjects of the research are the Principal / Madrasa, Religious Teachers, Civics Teachers, Social Sciences Teachers, Pesantren Guards and students or students. Data collection techniques are observation, interview, documentation. The research instrument is supported through interview guidelines, observation guidelines and documentation documentation. This study uses qualitative data analysis techniques with steps in analyzing the Miles et al., (2014) data models, namely 1) data reduction, 2) data presentation, 3) Conclusion or verification.

\section{RESULT AND DISCUSSION}

Schools are formal and non-formal educational institutions established both by the state and private sector to provide education to the nation's children so that intelligent and moral people are formed. The school organizes a variety of teaching and learning activities with students as the most important element to be taught and the teacher as the instructor who will provide instruction and shape the student's personality. The pattern of character formation is the way, procedure and steps taken by a teacher to form the character of students when they are in school.

\section{SMP Negeri 3 Watampone}

Efforts to form the character of students naturally require a method. So students are able to see the personality they have. In this article, the method used is seen from the aspect of the teacher's approach to students and the integrity of character education.

\section{1) Teacher's Approach to Students}

The character building of students at Watampone Middle School 3 is done by the teacher with a personal approach to students. As with teachers in general, giving advice 
86 | Jurnal Administrare: Jurnal Pemikiran Ilmiah dan Pendidikan Administrasi Perkantoran
Vol. 7, No. 1, January - June 2020, Pages 83-92

and reprimands in person to person respect students more than being reprimanded or scolded in front of their peers. Mental learners are strongly influenced by the state of students. As stated by one of the teachers whose initials ME states that:

"The approach is carried out with students who have problems, as long as I teach here there are some students who are stubborn, but not insolent at the teacher, they are asked if good and good response. So I personally deal with recalcitrant students by giving advice and words of motivation, if we are rude to their children, they become more stubborn, so to form good characters, we must use a good approach, too"

In line with this view, one of the teachers with the initials FA held that:

"Forming a character with a gradual approach I do the same as students who used to violate when I taught in class, the violations usually do not go to class, make noise and disturb my classmates, at first be reprimanded well first, if we still don't hear it then we call it privately and then be advised so as not to repeat his actions ".

A similar view was conveyed by one of the teachers with the initials IR stating that:

"The approach to students is very important, if students are always inculcated with moral values, it will affect their daily lives, students who have embedded moral values in themselves then it is not young to commit violations at school"

Forming the character of students through a personal approach according to some teachers is the most effective way, which can directly touch the student's personality as told by Mr. Asis S.Pd (WA KA Student) that "students when asked in front of their friends the reason for their actions, they are reluctant to answer, on the other hand if they are called in person and are asked carefully they just answer and want to state the reason.

\section{2) Integration of Character Education}

Subjects in junior high school based on k13 are not much different from general subjects in pesantren, Pancasila and Citizenship Education Lessons, Religious Education, and Social Studies contain the same material discussion, teachers as educators play an important role in this matter, teachers in each subject the. The teacher when explaining must emphasize the character points contained in each sample material: Norms material in PPKn subjects and etiquette material in religious education and character education. As stated by one of the teachers with the initials FA stated that:

"Character education is very influential in shaping student morals, PPKn subjects contain the core of character education, I as a teacher who has taught for several years here always emphasize that students come out of school with good behavior. There have been many alumni of SMP 3 who succeeded in becoming graduates when they met outside, they always shook my hand. " 
The same view expressed by the teacher whose initials IR he stressed the need for intermittent examples of moral acts and advice when explaining material related to character education. As said that:

"As a teacher, my job is to teach and change bad student attitudes into good, from the less intelligent to the smart, parents entrust their children in school to be formed and taught, we as teachers have regarded students as our children, I always give advice to good students before learning until finished, in my opinion students listen to advice and motivations rather than memorizing the subject matter.

\section{Student Character Building Strategy}

Extracurricular or commonly known as "eskul" is an activity carried out by students outside of class time, Watampone Middle School has two extracurricular groups, namely PMR and Scout. Based on some statements from the teacher, students who routinely attend the extracurricular are better known and on average they are students who are achievers and are polite. This was further emphasized by teachers who had the initials the US said that:

"Students who take extracurricular activities such as Boy Scouts, are different from other students, can be seen from their attitude, and closeness with the teacher, students who take extracurricular social relations are better, have a higher sense of selfconfidence. I always pay attention to student behavior, very much different is the attitude of students who are active in extracurricular with those who are not active, their characters are also different. "

Students who are involved in extracurricular activities have been trained in good self-reliance and mental attitude. This was confirmed by the school principal with the initials FI he said that "the character of students who take extracurricular activities is very quickly formed, clerical, independence and discipline are the most prominent characters"

Based on some of the opinions above, the character of a student is strongly influenced by the environment, the school is a place to shape the character of students into human characters, extracurricular activities greatly affect students' personalities because students need a place to channel what they learn in class by following extracurricular activities. for example PMR, students will get involved by helping people in need as well as Scouts who teach the value of high discipline and love the environment.

The three patterns of character formation contain three points, namely: 1) Habitation is formed because it is accustomed to and consistently carried out consistently for a long time so that the habit is difficult to leave; 2) Exemplary, students follow and copy what they see, role models emulated at school are Teachers, every action shown will shape the character of students, especially for students who really admire their teacher; 3) Culture is a habit that has become a routine that is always 
maintained so that the characters that have been formed are not young damaged by negative things.

\section{MTs Ma'had Hadits Al-Junaidiyah Biru}

The pattern of character formation in MTs Ma'had Hadith Al-Junaidiyah Biru consists of two forms: method and strategy. The method used is the same as SMP Negeri 3 Watampone by looking at two approaches, namely: from the aspect of the teacher's approach to students and the integrity of character education.

\section{Teacher's Approach to Students}

As a teacher who interacts daily with students / students both in and class must be good at reading conditions, take action when facing students who are indifferent, lazy to learn or do not respect the teacher, students in one class scope certainly have different characters. easy to advise and some are very difficult to hear the advice of teachers, therefore teachers must be able to take appropriate action. As stated by the teacher whose initials NU said that:

"The approach taken by the teacher is always approached by the children by giving advice and motivation, before learning the children are asked first what the problem is if someone does not go to school, after knowing the reason for not attending school, then they are personally called to be given again motivation"

The approach by giving advice and motivation by the mother with the initials NU is in line with what was stated by the teacher with the initials RA stating that:

"Before entering into learning children are given advice and told my experiences that can motivate children, usually children are very serious when told stories, they hear nothing noisy and talk to friends in the apartment. That's all the point is children are always approached and given advice especially to students who are naughty ".

In addition to conducting interviews with teachers in the field of study researchers observed by observing some student behavior when advised outside the classroom, from the observation of researchers, students who are being advised do not respond with many words only nodding and the word "iye pak" they say, the student's head is always looked down only occasionally looked at the teacher's face.

\section{Integration of Character Education in Subjects}

The emphasis of the characters as outlined in classroom learning is outlined in the "explicit curiculum" of junior high schools (SMP / MTs) having 10 subjects taught based on revision K13. Of the ten subjects, there are three subjects that describe the values of national character, namely Pancasila Education and Citizenship, Islamic Religious Education and Characteristics and Social Sciences. Through these three 
subjects the teacher can explain and give examples to students related to character education. Being a culture is a process that goes through stages: taught, accustomed to be trained, consistent, becomes a habit, becomes a character, becomes a culture. As stated by the teacher with the initials NU stated that:

"Religious subjects contain a lot of material on Islamic Shari'a, there is also material about praiseworthy behavior. Religious Studies are very good for students, especially students who are naughty, God willing, if the understanding of religion is good, also affects the morals, "

Another case with the teacher initials RA he stated that:

"Forming character through social studies does not really affect students, there is not much material specifically about morals such as religion, but there are a number of materials that discuss social interaction in my opinion, which is the closest to character education. The importance of the material is explained, but the most important thing is always given good examples to students "

In addition to social studies and Islamic education, PPKn subjects are the most important subjects for character building. The information from the teacher with the initials NU said that:

"In my opinion PPkn, is a place for moral teachings, the seventh grade material on norms is very appropriate given to new students, giving an understanding of norms interspersed with examples is my way to improve and instill morale in students, but students are different in nature, if I think there are students who do not behave politely indeed from his personality, especially MTS students are still immature all the thoughts of students, different if the Madrasah Aliyah is next to them as adults and long lived lodgings.

Based on the explanation above that the emphasis of the characters is poured in learning so that students directly apply the values of characters in class when learning. Through some of the information above, it can be understood that the formation of students in the MTS Ma'had Hadith Al-Junaidiyah Blue has been applied through subjects that contain material about character education.

\section{3).Character building strategy}

\section{a. Morning Ceremony}

Before entering the room the morning ceremony routine is a routine at the AlJunaidiyah Blue Bone Islamic Boarding School both at the Aliyah and Tsanawiyah levels, the morning ceremony is applied to train the students' discipline. Besides that, the morning ceremony was directly led by the Madrasah Head as the leader in the Madrasa, directives and moral messages did not escape delivered to students to provide ruhiyah intake.

As the principal of the school with the initials US said that: 
" Morning ceremony Suda routine here, disciplining students is the duty of Islamic boarding schools based on the rules that have been set, students here are mostly children of office employees, most also from villages entered here with different behaviors, from the quietest to the most naughty. We as the party responsible must be able to change these characteristics. Besides teaching the discipline of giving direction, advice and moral messages, we always emphasize every day, this is very useful to give awareness to students. "

This is in line with what was said by the teacher JA as the caretaker of the hut stated that:

"Apples are applied here every morning for a long time, students here mostly live in lodgings, students are late for the morning apple rarely, if there are late usually only a few people. the principal always gives the message before the ranks are disbanded.

\section{b) Prayers in congregation}

In general, Madrasas have mosque or mushollah facilities located within the Madrasah environment, for Islamic boarding schools having facilities such as mosques is very important, pesantren and matters relating to worship and religion cannot be separated. The mosque is a gathering place for students to perform compulsory worship, sunnah and other practices such as memorizing the Qur'an, reciting and studying the Yellow Book or Memorizing the Hadith. In Islamic boarding schools praying in congregation is an obligation for students. At the time of prayer in congregation students can learn how to say good, be polite and polite, respecting his fellow brothers and sisters, and intertwining brotherhood.

Based on the results of observations made by researchers during the research that is "students in the mosque area on average students look to memorize the Qur'an when researchers enter the pesantren area the students seemed friendly respecting guests who come to visit". After performing the congregational prayers interspersed with short lectures delivered by students who have been appointed, the lecture is a delivery in the form of religious advice and guidance, students who are used to hearing good words will then form a good character with youth. As stated by the head of Madrasa that: "Prayer in congregation must be carried out, students who keep their prayers avoid vain deeds, we are never bored to scare the students".

\section{CONCLUSION}

Based on the description above it can be concluded that: 1) To form the character of students in MTs Ma'had Hadith Al-Junaidiyah Blue Teachers as educators use patterns or several ways according to them which are young and strategic ways to shape students 
'characters namely Teachers' Approach to Students / santri, Integrity of Character Education Through Pancasila and Citizenship Education (PPKn) subjects and Islamic Religious Education and Social Sciences and Social Sciences Education, morning Apple is conducted to discipline students and in the implementation of the morning apple the ceremonial leader always conveys directions and messages. moral in order to form the character of the students and the routine prayer in congregation obligatory for the students, tadarrus together and cult through these activities the religious values that exist in students are maintained, 2) The pattern of character formation found in SMPN 3 Watampone consists of 3 formation patterns that are the most dominant is used to form the character $r$ students namely the teacher approach students, Integration of character education in several subjects such as Islamic Religious Education, Pancasila and Citizenship Education (PPKn) and Social Sciences Education, furthermore character building through school extracurricular activities is one way for teachers of SMP 3 Watampone to shape the character of participants students, full support and appreciation from the teacher motivates students to participate in joining various extracurricular activities provided by the school.

\section{REFERENCES}

Andreadou, I., Papalois, A., Triantafillidis, J. K., Demonakou, M., Govosdis, V., Vidali, M., Anagnostakis, E., \& Kourounakis, P. N. (2002). Beneficial effect of a novel non-steroidal anti-inflammatory agent with basic character and antioxidant properties on experimental colitis in rats. European Journal of Pharmacology, 441(3), 209-214. https://doi.org/https://doi.org/10.1016/S0014-2999(02)01410-3

Awaru, A. O. T. (2017). Membangun Karakter Bangsa Melalui Pendidikan Berbasis Multikultural Di Sekolah. Prosiding Seminar Nasional Himpunan Sarjana Ilmu-Ilmu Sosial, 2, 221-230.

Castro, M. C., Arce, A., Soto, A., \& Rodríguez, H. (2016). Liquid-liquid equilibria of mutually immiscible ionic liquids with a common anion of basic character. The Journal of Chemical Thermodynamics, 102, 12-21. https://doi.org/https://doi.org/10.1016/j.jct.2016.05.023

Hamzah, A. N. (2019). Degradasi Kader Tarbiyah Islamiyah Pada Study Club Al Furqan Fakultas Ilmu Sosial Universitas Negeri Makassar. Universitas Negeri Makassar.

Kahar, F., Asse, A., Nasrullah, M., Akib, H., \& Saslam, R. (2019). Role of Village Head as Development Administrator in Mattirowalie Village Maniangpajo subdistrict Wajo District. International Conference on Social Science 2019 (ICSS 2019).

Kardilla, K., \& Awaru, A. O. T. (2018). Perilaku Sosial Pengamen Pada Pelajar Di Kota Palopo. JURNAL SOSIALISASI, 47-50.

Lickona, T. (1999). Character education: Seven crucial issues. Action in Teacher Education, 20(4), 77-84.

Miles, M. B., Huberman, A. M., \& Saldana, J. (2014). Qualitative Data Analysis: A Methods Sourcebook (3rd ed.). Sage Publications.

Niswaty, R., Darwis, M., Alimuddin, W., \& Salam, R. (2016). Pengaruh Penerapan Prinsip Good Governance terhadap Efektivitas Kerja Pegawai. Jurnal Ilmiah Administrasi Publik (JIAP), 95-100. 
92 Jurnal Administrare: Jurnal Pemikiran Ilmiah dan Pendidikan Administrasi Perkantoran Vol. 7, No. 1, January - June 2020, Pages 83-92

Nurlailah, N., \& Awaru, A. O. T. (2018). Strategi Guru Dalam Pembentukan Karakter Siswa Di Sma Negeri 1 Bissappu Kabupaten Bantaeng. JURNAL SOSIALISASI, 102-107.

Procter, R. A., \& Wilson, D. C. (1995). Interpretation of a basic hypergeometric identity with Lie characters and Young tableaux. Discrete Mathematics, 137(1), 297-302. https://doi.org/https://doi.org/10.1016/0012-365X(93)E0131-M

Saggaf, S., Salam, R., Kahar, F., \& Akib, H. (2014). Pelayanan Fungsi Administrasi Perkantoran Modern. Jurnal Ad'ministrare, 1(1), 20-27.

Salam, R., \& Rosdiana. (2015). Penerapan Fungsi Administrasi Perkantoran Modern berbasis Daya Saing Organisasi dalam menyongsong MEA 2015. SEMINAR NASIONAL "Revolusi Mental Dan Kemandirian Bangsa Melalui Pendidikan Ilmu-Ilmu Sosial Dalam Menghadapi MEA 2015” Himpunan Sarjana Pendidikan Ilmu-Ilmu Sosial Indonesia, 1, 186-190. 